\title{
Effect of modified clays on the structure and functional properties of biofilms produced with zein
}

\author{
Efeito das argilas modificadas na estrutura e propriedades funcionais de biofilmes produzidos com zeína
}

\author{
Luciana Lopes TAVARES ${ }^{1}$, Crislene Barbosa DE ALMEIDA ${ }^{1}$, Ícaro Putinhon CARUSO ${ }^{2}$, \\ Marinônio Lopes CORNÉLIO ${ }^{2}$, José Francisco LOPES FILHO ${ }^{1 *}$
}

\begin{abstract}
The purpose of this study was to evaluate changes in the structure and some functional properties of biofilms added with modified clays (Cloisite $15 \mathrm{~A}$ and Cloisite ${ }^{\circledast} 30 \mathrm{~B}$ ) prepared by the casting method. The analysis of the microstructure of the films, scanning electron microscopy (SEM), Optical microscopy (MO), and Infrared Spectroscopy (FTIR) indicated that the addition of clay in the films resulted in the formation of a heterogeneous microstructure, microcomposite or tactoid. Due to the formation of a microcomposite structure, functional properties of the films added with both clays such as opacity, solubility, and permeability to water vapor (PVA), were not better than those of the control film. Thus, it was concluded that although it is possible to produce a film added with modified clays using the casting method, it was not possible to obtain intercalation or exfoliation in a nanocomposite, which would result in improved functional properties.
\end{abstract}

Keywords: biofilms; zein; clays; microcomposite; tactoids.

\section{Resumo}

O propósito deste estudo foi avaliar mudanças na estrutura e em algumas propriedades funcionais de biofilmes de zeína adicionados de argilas modificadas (Cloisite ${ }^{\circledR} 15 \mathrm{~A}$ e Cloisite ${ }^{\circledast} 30 \mathrm{~B}$ ) elaborados pela técnica casting. Por meio do uso de técnicas de análise de microestrutura dos filmes, Microscopia Eletrônica de Varredura (MEV), Microscopia Ótica (MO) e Espectroscopia no Infravermelho (FTIR), observou-se que os acréscimos de argilas resultaram na formação de uma microestrutura heterogênea, formando um microcompósito ou tactoide. Devido à formação da estrutura tipo tactoide, as propriedades funcionais de opacidade, solubilidade e permeabilidade ao vapor d'água (PVA), para os filmes adicionados de argilas, não foram melhores do que as obtidas para o filme controle. Assim, concluiu-se que é possível elaborar um filme adicionado de argilas modificadas usando a técnica casting, porém não foi possível obter intercalação ou esfoliação em nanocompósito, os quais resultariam em melhores propriedades funcionais.

Palavras-chave: biofilmes; zeína; argilas; microcompósitos; tactoides.

\section{Introduction}

Nowadays, there has been considerable interest in the development of biodegradable materials as a possible contribution to solving environmental problems since plastics developed by industry made from fossil fuels are almost non-degradable (SORRENTINO; GORRASI; VITTORIA, 2007). In recent years, several studies have been conducted to develop and characterize biofilms with the potential for application in the fields of food and agriculture. The polymers used for the production of biofilms are extracted or removed from the biomass (proteins and polysaccharides), produced by microorganisms (xanthan, etc.), or through chemical synthesis of renewable bio-based monomers, or yet, alternatively, through the mixture of biomass and oil (BATISTA; TANADA-PALMU; GROSSO, 2005; YU; DEAN; LI, 2006).

Among those sources, zein, a protein from corn, has been used as an important material in science and industry for its unique properties. In addition to being biodegradable and renewable, it offers potential advantages as a raw material for biofilms, coatings, and plastic applications (LAWTON, 2002). However, in general, polymers exhibit poor mechanical and barrier properties, which must be improved so that they can be used in different situations. Polymers produced with the addition of nanoparticles often exhibit better properties than conventional composites such as increased strength, better consistency, higher thermal and oxidative stability, better barrier properties to gases and water, and flame retardance (PAVLIDOU, PAPASPYRIDES, 2008). These improved properties are usually achieved by space filled in the polymer matrix in comparison with conventional materials. With regard to biodegradability, these materials also have advantages (SOZER, KOKINI, 2009).

Therefore, this study aimed to elaborate zein films added with different clays and evaluate the interactions between the

\footnotetext{
Received 06/08/2010

Accepted 23/02/2012 (004965)

Department of Food Engineering and Technology, São Paulo State University - UNESP, Rua Cristóvão Colombo, 2265, CEP 15054-000, São José do Rio Preto, SP, Brazil,

e-mail:lopes@ibilce.unesp.br

2 Physics Department, São Paulo State University - UNESP, Rua Cristóvão Colombo, 2265, CEP 15054-000, São José do Rio Preto, SP, Brazil

${ }^{*}$ Corresponding author
}

http://dx.doi.org/10.1590/S0101-20612012005000056 
components of the films as well as changes in some functional properties.

\section{Material and methods}

\subsection{Materials}

The films were prepared with corn zein, regular grade (F4000) purchased from Freeman Industries, Inc. (U.S.A), ethanol 99\% (Synth, BRA) used as solvent, oleic acid from VETEC (BRA), glycerol as assistant agent or plasticizer from Merck (BRA), and an emulsifier as stabilizer from EMUSTAB - Duas Rodas Industrial Ltda. (BRA). The modified clays (Cloisite ${ }^{\circledast} 15 \mathrm{~A}$ and Cloisite ${ }^{\circledast}$ 30B) were kindly supplied by Southern Clay Products Inc. (U.S.A).

The two organically modified montmorillonite clays were prepared by reacting a tallow having quaternary ammonium counter ion with natural montmorillonite clay at the concentrations of 43\% (Cloisite $15 \mathrm{~A}$ ) and 30\% (Cloisite ${ }^{\circledast} 30 \mathrm{~B}$ ). Both clays contain a mixture of alkanes consisting of $\sim 65 \% \mathrm{C} 18$, $\sim 30 \% \mathrm{C} 16$, and $~ 5 \% \mathrm{C} 14$.

\subsection{Methods}

\section{Preparation of the films}

The control film was prepared according to Kleen, Padua and Engeseth (2002), with some adaptations, by dissolving granular zein in a $75 \%$ aqueous ethanol to a concentration of $16 \%$ (by mass per volume) at room temperature. Oleic acid was added at a ratio of $70 \mathrm{~g}$ per $100 \mathrm{~g}$ of zein, and glycerol was added at a ratio of $30 \mathrm{~g}$ per $100 \mathrm{~g}$ of zein, while stirring the solution in a water bath at 60 to $65^{\circ} \mathrm{C}$. The clays were also added at a ratio of 1,2 , and $4 \%$ of clay/zein, i.e., to $1 / 100,2 / 100$ and $4 / 100 \mathrm{~g}$ ( $\mathrm{g}$ of clays to $100 \mathrm{~g}$ of zein).

In order to prepare films with both clays, the clay was first dispersed in $15 \mathrm{~mL}$ of water under stirring for 10 minutes. This mixture was slowly added to the solution of zein-ethanol already containing oleic acid, glycerol, and emulsifier, which were prepared in the same proportion and conditions of the control film. The resulting solution was stirred for 10 minutes at $250 \mathrm{rpm}$ at a temperature of 63 to $65^{\circ} \mathrm{C}$ and poured on a flat surface to dry. After drying, the films formed were peeled off and stored in a desiccator at 58\% relative humidity until analyses.

\subsection{Characterization of biofilms}

Visual Aspects investigated the homogeneity of the samples (without insoluble particles), uniformity in thickness, and good malleability.

Thickness of the films was determined by the arithmetic mean of six values measured in six randomized points of each sample using a digital micrometer (DIGIMESS, IP 54, BRA) with $0.001 \mathrm{~mm}$ resolution.

\section{Microstructure}

Scanning Electron Microscopy (SEM) was performed with film samples of $12 \mathrm{~mm}$ in diameter fixed onto stubs with double-sided adhesive tape with conductive copper and covered with $35 \mathrm{~nm}$ of gold (EMITEC K550, UK). Samples, taken in duplicate, were observed under an electronic microscope (LEO $435 \mathrm{VP}, \mathrm{UK})$ at $15 \mathrm{kV}$ in a climate room.

Optical Microscopy (OM) was used to identify the compounds formed in films stained with Xylidine Ponceau $(\mathrm{pH}=3.5)$. The samples, taken in duplicate, were stained directly without previous fixation and dehydration because zein is soluble in alcohol solutions, which are used to fix the material. Instead of fixing the samples with ethanol-base solution, glass slides (ODONTOBRAS ECB 1.2 Digital, BRA) at $37^{\circ} \mathrm{C}$ mounted with Canada Balsam were used. After 24 hours, the samples were analyzed at room temperature using an optical microscopy (OLYMPUS BX 60, U.S.A) with an image capture system OLYMPUS DP 71, U.S.A. Different points in the sample were observed with $10 \times$ magnification.

Fourier transforms infrared spectroscopy with attenuated total reflectance accessory (FTIR-ATR) spectra were obtained using a Spectrometer Nicolet Nexus 670 FT-IR, U.S.A. Samples of $7 \times 70 \mathrm{~mm}$ were fixed in the ATR, and the spectra were recorded in the range from 4000 to $1200 \mathrm{~cm}^{-1}$, with a resolution of $4 \mathrm{~cm}^{-1}$ and 128 scans. 2D IR synchronous and asynchronous correlation plots were computed using MATLAB software developed in-house according to the generalized 2D correlation algorithm (NODA, 2003). 2D IR correlation plots were constructed with a spectral region of 1200 to $4000 \mathrm{~cm}^{-1}$ and were presented as contour maps.

\section{Functional properties}

Opacity was determined with a UV/VIS spectrophotometer (QUIMIS, Q798, BRA), as proposed by Gounga, Xu and Wang (2007). Samples of rectangular shape were applied to the internal wall of the cuvette. Three replications were done for each film at $600 \mathrm{~nm}$. Film transparency was calculated by dividing the absorbance at $600 \mathrm{~nm}$ by film thickness.

Water Solubility was determined in triplicate, according to the method proposed by Gontard, Guilbert and Cuq (1993). Samples of $2.0 \mathrm{~cm}$ in diameter were immersed in $50 \mathrm{~mL}$ distilled water, and the system was slowly mechanically stirred (72 rpm) at $25 \pm 1{ }^{\circ} \mathrm{C}$ in a shaker (MARCONI, MA-410, BRA) for 24 hours. After this period, they were removed from the solution and dried in an air oven (105 ${ }^{\circ} \mathrm{C}, 24$ hours). The difference in weight was used to measure the water soluble matter as a percentage of the initial weight.

Water vapor permeability of the samples was determined by the standard method E-96-95 of the American Society for Testing and Material (AMERICAN..., 2002). The films were weighed for eight days until the mass became constant.

Statistical Analysis of variance (ANOVA) was performed considering a randomized experimental design, and the Tukey's test was applied to compare data means at 5\% probability using the Statistica 7.0 software (Statsoft). 


\section{Results and discussion}

\subsection{Characterization of biofilms}

Visual aspects

The films used in the analyses were previously classified visually according to the homogeneity of the samples (free of insoluble particles), thickness uniformity, and malleability. Among the seven film samples evaluated, only the film with $4 \%$ of Cloisite ${ }^{\varpi} 15 \mathrm{~A}$ did not exhibit these characteristics showing fine insoluble particles after drying.

\section{Thickness}

Control film thickness ranged from 0.14 to $0.20 \mathrm{~mm}$, and that of the film samples with the clays ranged from 0.22 to $0.28 \mathrm{~mm}$.

\subsection{Microstructure}

\section{Scanning Electron Microscopy (SEM)}

Figure 1 presents the images obtained for the control and film samples added with 1, 2 and $4 \%$ of Cloisite $15 \mathrm{~A}$ and 1 , 2 and $4 \%$ of Cloisite ${ }^{\circledast} 30 \mathrm{~B}$.

According to Padua and Wang (2002), films produced via the casting method show different morphological shapes due to drying. The side in contact with air presents irregular and opaque appearance with black globular microstructure deposits.
Regarding the nature of these globular deposits, Monterrey-Quintero and Sobral (2000) suggested that these spots are micro-bubbles embedded in the matrix or spaces occupied by glycerol prior drying. However, Corradini (2004) stated that another possibility is the phase separation between the zein and glycerol due to the low interaction between these two components.

De Almeida et al. (2010), performing analysis of scanning electron microscopy on zein films prepared with oleic acid and glycerol, also observed the formation of round black spots. To identify the presence of globular deposits, these authors performed analysis of optical microscopy and concluded that what was previously considered by SEM as pores were indeed lipid globules dispersed in the filmogenic matrix.

The components of the film are indicated by arrows of different colors in Figure 1. The green arrows show the presence of pores and red arrows lipid globules, yellow arrows show a probable incorporation of the clay in the matrix, and blue arrows highlight the clay dispersion, i.e., it shows that the clay is not incorporated into the protein matrix. Comparing the image of the control film (a) with the others in Figure 1, it can be seen a predominance of pores and lipid globules on the control film indicating a more uniform structure. However, the films with clay showed heterogeneous structure as a function of poor scattering matrix. The higher the clay concentration in the formulation of the film, the lower the dispersion in the matrix forming embedded zones.
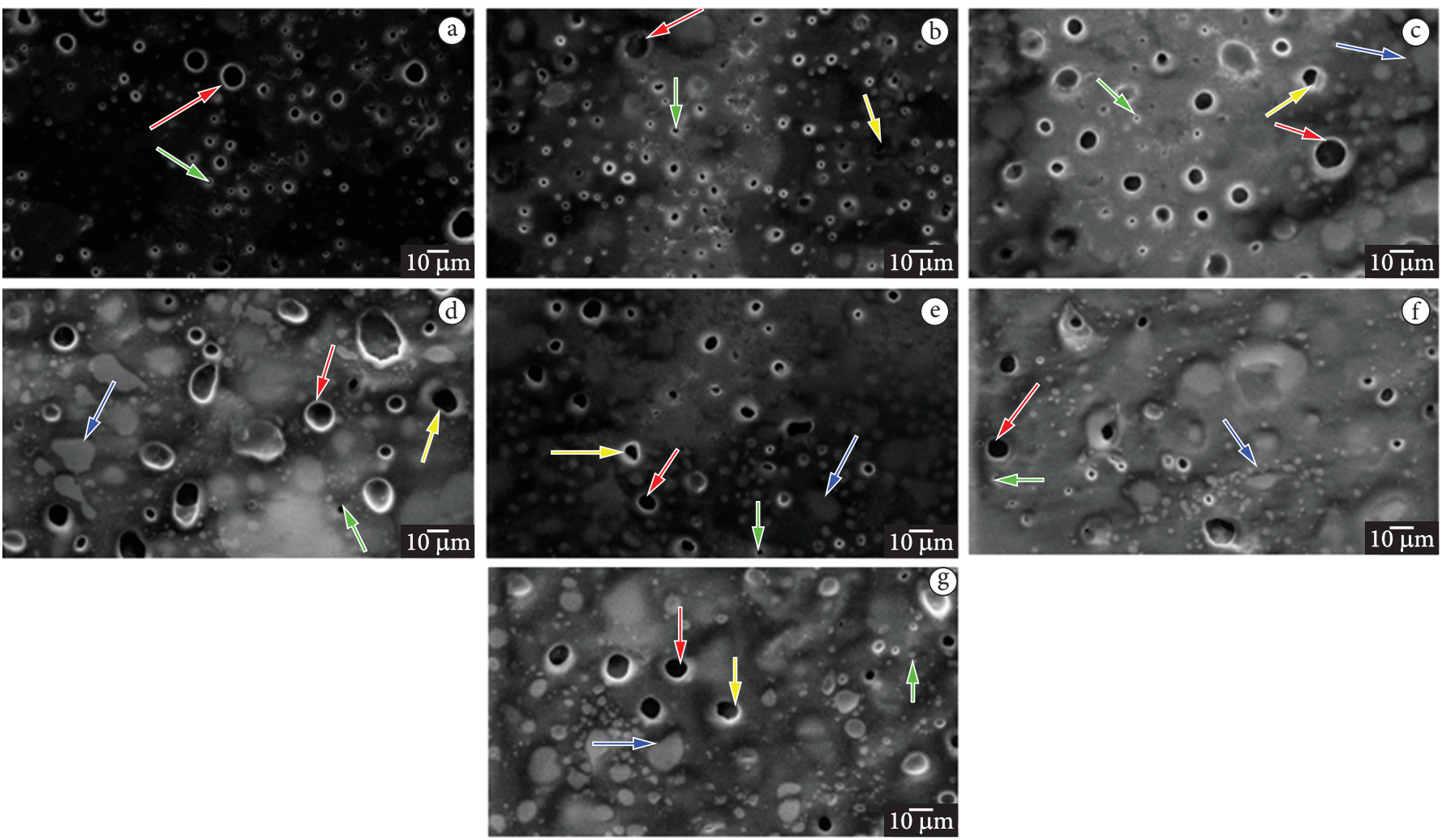

Figure 1. Micrographs obtained by Scanning Electron Microscopy (SEM) of films: (a) control, (b) 1\% Cloisite $15 \mathrm{~A}$, (c) $2 \%$ Cloisite $e^{\circledR} 15 \mathrm{~A}$, (d) $4 \%$ Cloisite $^{\oplus}$ 15A and (e) 1\% Cloisite ${ }^{\oplus}$ 30B, (f) $2 \%$ Cloisite $^{\oplus}$ 30B and (g) 4\% Cloisite ${ }^{\oplus}$ 30B. 
In a recent study, Arora and Padua (2010) found that clay dispersion in polymer matrices is affected by the hydrophobic/ hydrophilic characteristic of polymers and clays. The polymers are typically hydrophobic, while clays are more hydrophilic. The modified clays make film surfaces more hydrophobic improving their compatibility with polymers. According to these authors, the nanoparticles are able to disperse in the polymer matrix if their sizes are smaller than the radius of gyration of the polymer.

Although Cloisite ${ }^{\circ} 30 \mathrm{~B}$ is a clay modified with quaternary ammonium salt, it contains cluster- $\mathrm{OH}$, which makes it more hydrophilic than the other clay used in this study. However, using an array of predominantly hydrophobic behavior (zein) resulted in a low incorporation of nanoparticles. Figure $1 \mathrm{~g}$ shows the tactoids and agglomerations of non-dispersed particles. According to the observations of Arora and Padua (2010), the clays used in the present study, although modified, were not able to interact with the matrix protein. The main reason is that the interlayer spacing of Cloisite ${ }^{\bullet} 15 \mathrm{~A}$ and Cloisite ${ }^{\circ}$ $30 \mathrm{~B}$ is 31.5 and $18.5 \AA$, respectively. These values are higher than those found for films of zein-oleic acid by Wang et al. (2005) using X-ray diffraction of high angles (WAXS). These authors obtained peaks between 4.5 and $10 \AA$. Therefore, since the size of the nanoparticles is higher than the internal spacing of the zein array, it is impossible to fit the clay particles inside the matrix.

McAdam, Hudson and Pethrick (2008) stated that to promote the intercalation of clays in polymer matrices it is necessary to use techniques with high shear force or ultrasound to break up the clusters of the product (format cells of clays), which results in greater surface area exposed to interact with the polymer. However, in a recent study on the development of blends with carrageenan and zein carried out by Sanchez-Garcia, Hilliou and Lagaron (2010), it was possible to obtain a dispersed morphology in zein/carrageenan film added with mica. These authors observed by scanning electron microscopy (SEM) that only the films made with zein, glycerol (plasticizer) and mica showed very little clay dispersion when compared with those of the blend of carrageenan and zein with the addition of up to $5 \%$ of mica. They concluded that zein had little affinity to the clay.

In the present study, several factors may have contributed to form heterogeneous film after clay addition. One is the mixing technique and casting method, which were unable to promote a better dispersion of clay due to low interaction energy (shear) between the components. The homogenization of the clay in water may also have been insufficient, and finally, the type of clays which have particles with larger sizes than the interlayer spacing of zein array. Furthermore, this emphasizes the low affinity of zein with clay under the conditions considered in this study.

\section{Optical Microscopy (OM)}

Figure 2 shows the images of optical microscopy (OM) obtained respectively for the control and film samples added with 1,2 , and $4 \%$ of Cloisite ${ }^{\oplus} 15 \mathrm{~A}$, and 1,2 , and $4 \%$ of Cloisite ${ }^{\circledR} 30 \mathrm{~B}$.

The images were obtained by Xylidine Ponceau technique, which provides two types of staining. The red color represents the fraction of protein (zein) and the white spots indicated by arrows represent the lipid globules. In principle, observing
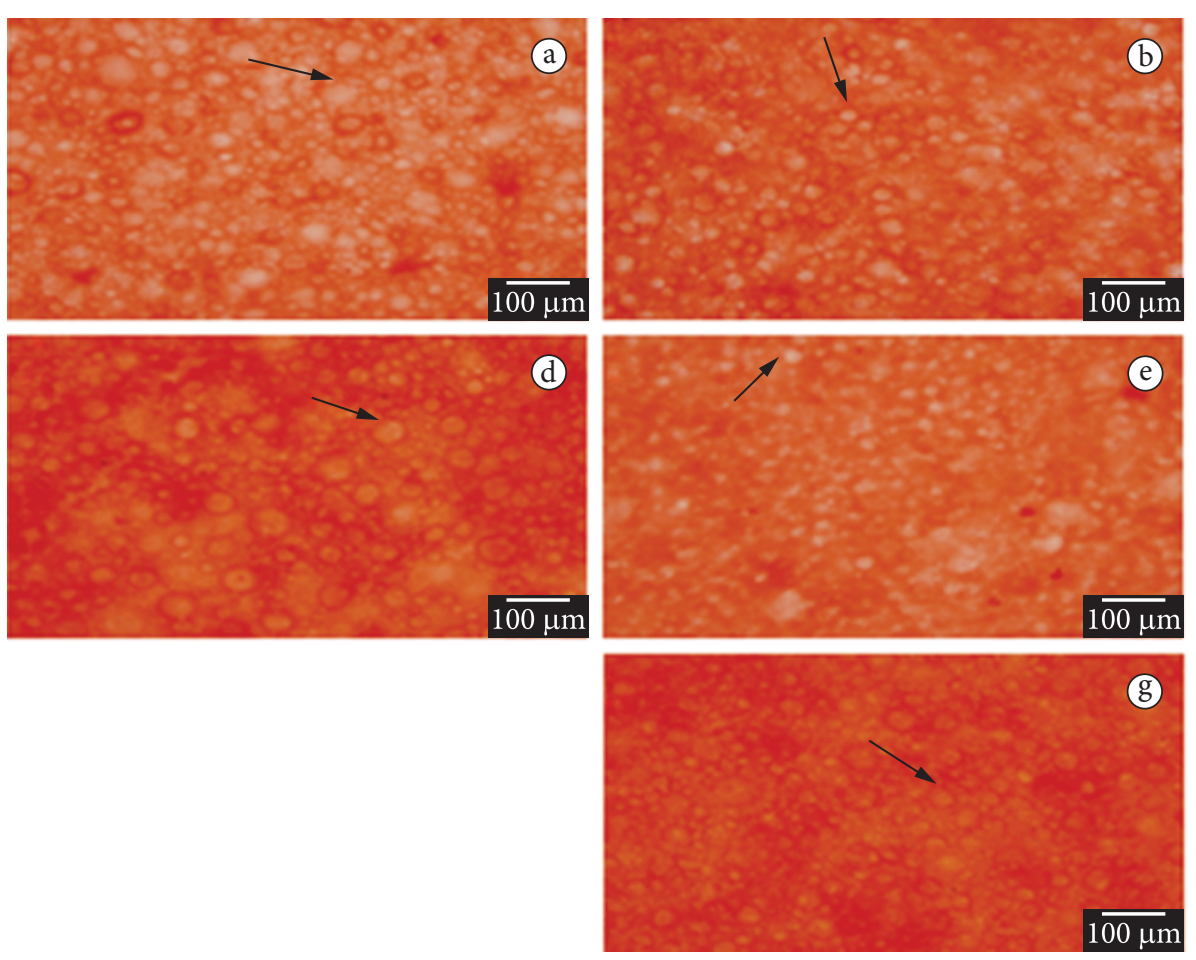
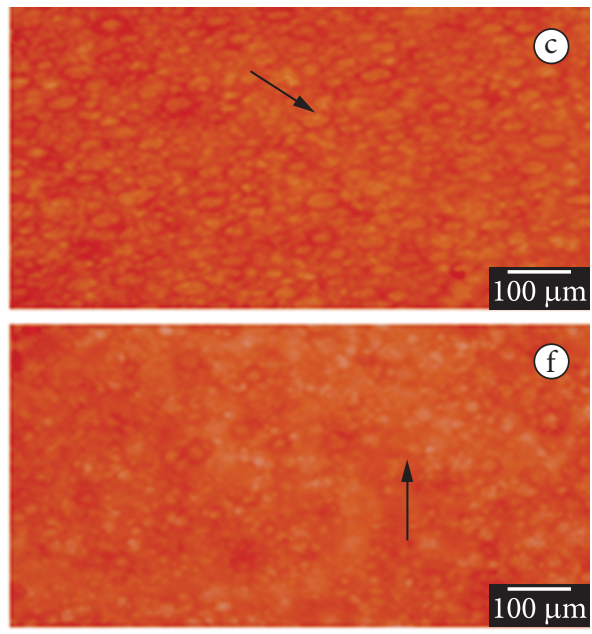

(8)

Figure 2. Image Optical Microscopy with Xylidine Ponceau for biofilms: (a) control, (b) $1 \%$ Cloisite $15 \mathrm{~A}$, (c) $2 \%$ Cloisite $15 \mathrm{~A}$, (d) $4 \%$ Cloisite $15 \mathrm{~A}$ and (e) $1 \%$ Cloisite $^{\circledast}$ 30B, (f) $2 \%$ Cloisite $^{\circledast}$ 30B, and (g) $4 \%$ Cloisite $^{\circledast} 30 \mathrm{~B}$. 
the images in Figure 2, it was assumed that increasing the concentration of clays caused decreases in the size of lipid globules. In order to check if the amount of clays influenced decreases in size, it was selected 20 similar globules to measure their sizes. Using the software Image-Pro Plus ${ }^{\oplus}$ Media Cybernetics version 4.5, the diameters were measured in triplicate for each film sample. Statistical analyses of the values were performed for comparisons. Table 1 presents the results.

The sample with $1 \%$ Cloisite ${ }^{\circledR} 15 \mathrm{~A}$ differed significantly from the other films showing a size of lipid globules with intermediate mean diameter of $74.59 \mu \mathrm{m}$.

Film samples with $1 \%$ of Cloisite $30 \mathrm{~B}, 2 \%$ of Cloisite $30 \mathrm{~B}$, and $4 \%$ of Cloisite $30 \mathrm{~B}$ were not different, but the sizes of their lipid globules were significantly lower than those of control sample and those added with Cloisite ${ }^{\circ} 15 \mathrm{~A}$. There is no evidence showing any tendency of the clay particles affecting the globules size. It can be supposed, however, that the procedure of mixing the clay in the filmogenic solution was the main factor affecting the dispersion in the film.

Recently, De Almeida et al. (2010), also using optical microscopy with the technique of Xylidine Ponceau, found that the addition of xanthan gum in higher concentrations caused decrease in the size of lipid globules in zein biofilms. They concluded that this decrease was due to a better homogenization of the fatty acid in the matrix. That fact was not observed in this study, as shown by the SEM analysis. Unlike the observation of these authors, the data in Table 1 show a decrease in lipid globules size only for the film samples with addition of Cloisite ${ }^{\bullet}$ 30B. However, it is observed in Figure 2 that there was a uniform distribution of the globules and protein in all films.

\section{Two-dimensional correlation spectroscopy with FTIR-ATR}

The ATR-FTIR spectra obtained for the film of zein-oleic acid (control) is shown in Figure 3.

Analyzing the spectrum, a number of bands associated with a vibrational mode that characterizes some specific chemical groups can be seen. The bands presented in Figure 3 indicate the presence of vibrational modes assigned to the amide III around $1400 \mathrm{~cm}^{-1}$, amide I at $1650 \mathrm{~cm}^{-1}$, oleic acid in 1747,2850 , and in $2956 \mathrm{~cm}^{-1}$, and amide A in $3300 \mathrm{~cm}^{-1}$ characterizing the composition of the film based upon the protein. To show the possible correlations between functional groups, it was necessary to use a more detailed analysis, the two dimensional map.

Table 1. Mean diameter of lipid globules inside biofilms of zein.

\begin{tabular}{|c|c|}
\hline Samples & Diameter $(\mu \mathrm{m})$ \\
\hline Control (Zein) & $88.35 \pm 15.63^{\mathrm{a}}$ \\
\hline Zein + Cloisite $^{\oplus} 15 \mathrm{~A}(1 \%)$ & $74.59 \pm 15.59^{c}$ \\
\hline Zein + Cloisite $^{\bullet} 15 \mathrm{~A}(2 \%)$ & $88.57 \pm 17.30^{\mathrm{a}}$ \\
\hline Zein + Cloisite $^{\circ} 15 \mathrm{~A}(4 \%)$ & $94.03 \pm 23.02^{\mathrm{a}}$ \\
\hline Zein + Cloisite $^{\bullet} 30 \mathrm{~B}(1 \%)$ & $63.35 \pm 16.71^{\mathrm{b}}$ \\
\hline Zein + Cloisite $^{\oplus} 30 \mathrm{~B}(2 \%)$ & $70.38 \pm 16.93^{b c}$ \\
\hline Zein + Cloisite $^{\bullet} 30 \mathrm{~B}(4 \%)$ & $68.28 \pm 15.09^{\mathrm{bc}}$ \\
\hline
\end{tabular}

$\overline{a, b, c}$ - Means followed by same letter in same column do not differ by Tukey's test $(\mathrm{p}<0.05)$.
Figure 4 shows the synchronous two-dimensional map for the biofilm added with Cloisite ${ }^{\bullet} 15 \mathrm{~A}$. In this figure, it can be observed two regions along the main diagonal; the region around $1640 \mathrm{~cm}^{-1}$ is related to the stretching of $\mathrm{C}=\mathrm{O}$ group. The second region refers to the structure of leaf- $\beta$. It can also be observed in the $2930 \mathrm{~cm}^{-1}$ region a stretching of a $\mathrm{CH}$ group that possibly belongs to $\mathrm{CH}_{3}^{-}, \mathrm{CH}_{2}^{-}$, or $\mathrm{CH}-$. Positive cross peaks are found between $29231657,2923 \times 1528,2884 \times 1585 \mathrm{~cm}^{-1}$. These peaks imply the susceptibility of some vibrational modes which can indicate some interaction between two or more components of the film, i.e., there is some kind of interaction between zein and oleic acid or glycerol. According to Madejová (2003), clays show characteristic peaks in regions near $3620 \mathrm{~cm}^{-1}$, which was not observed for these samples.

The asynchronous spectrum refers to films with Cloisite ${ }^{\circ}$ $15 \mathrm{~A}$ (Figure 4 ). There are a number of positive peaks in $1640 \times 1590 \times 1646 \times 1374,1500$, and $1646 \mathrm{~cm}^{-1}$. They are cross-peaks suggesting secondary structures represented by $\alpha$ and $\beta$-sheet, which are more susceptible to clay concentration increases. The set of negative cross-peaks in $2913 \times 1650$, 1642 and $1702 \times 2851 \times 1636 \mathrm{~cm}^{-1}$ indicate frequencies that coincide with the vibrational modes obtained in the positive peaks with a slight shift towards the region in $1636 \mathrm{~cm}^{-1}$. Therefore, this set of two-dimensional maps indicates that the presence of clay exerted some influence on the secondary structure of the protein indicating steric hindrance of the clay-protein interaction.

Figure 5 corresponds to the synchronous two-dimensional map of the zein film composed of 1,2 , and $4 \%$ of Cloisite ${ }^{\circledast} 30 \mathrm{~B}$. According to the peaks on the main diagonal, two regions are observed. The most expressive intensities around $3000 \mathrm{~cm}^{-1}$ are due to the stretching of the $\mathrm{CH}$ group from $-\mathrm{CH}_{3}, \mathrm{CH}_{2}$, or $-\mathrm{CH}$ - belonging to oleic acid or glycerol (LEE, CONDRATE,

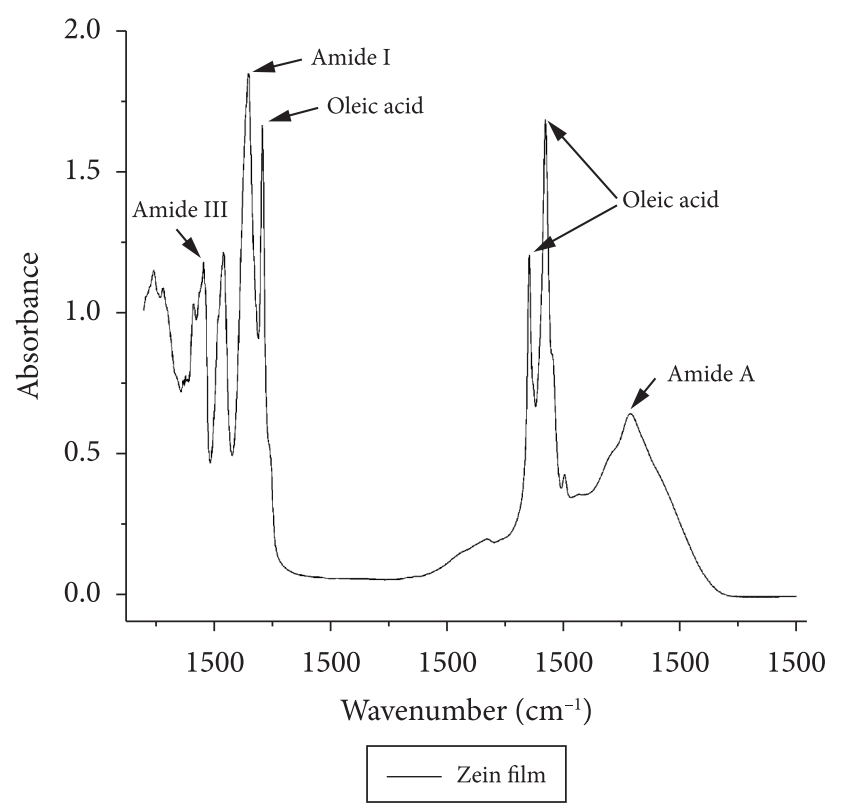

Figure 3. FTIR- ATR spectrum of zein biofilm (control). 
(a)

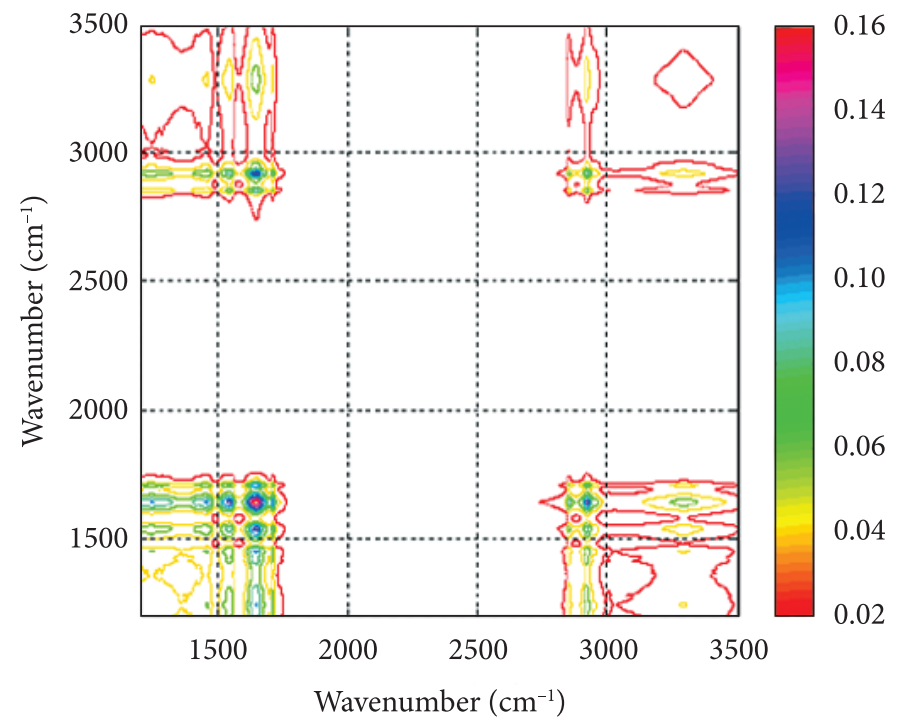

$\times 10^{3}$ (b)

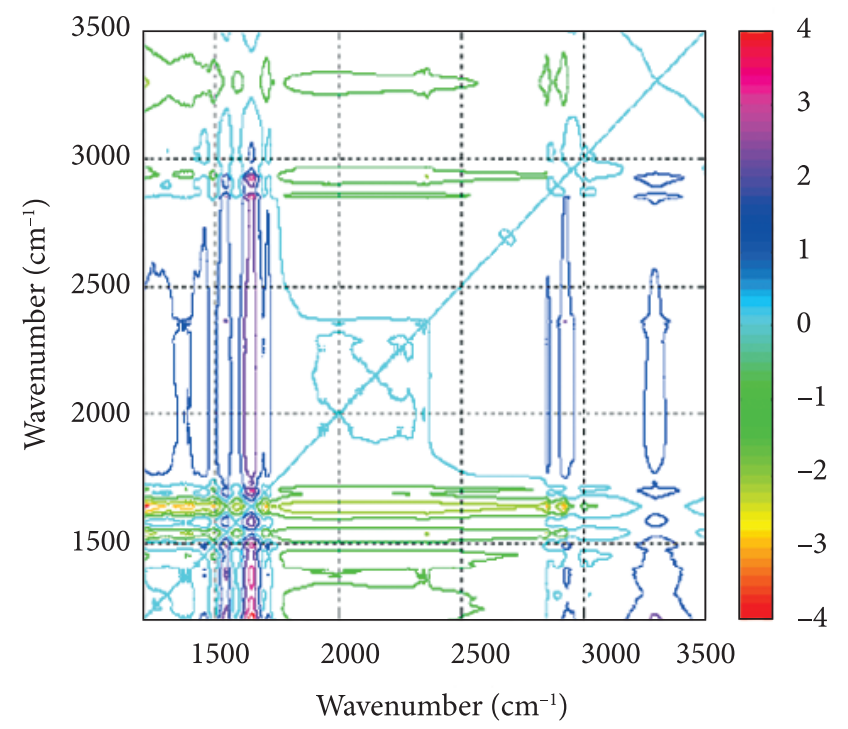

Figure 4. (a) Synchronous and (b) Asynchronous two-dimensional correlation spectrum of zein showing functional groups affected by the addition of 1,2 , and $4 \%$ Cloisite $15 \mathrm{~A}$.

(a)

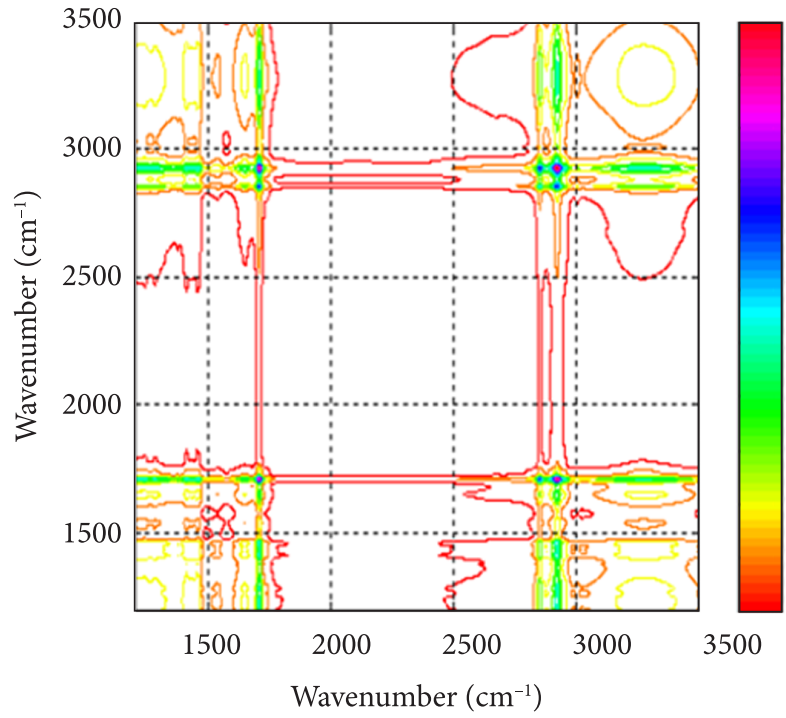

(b)

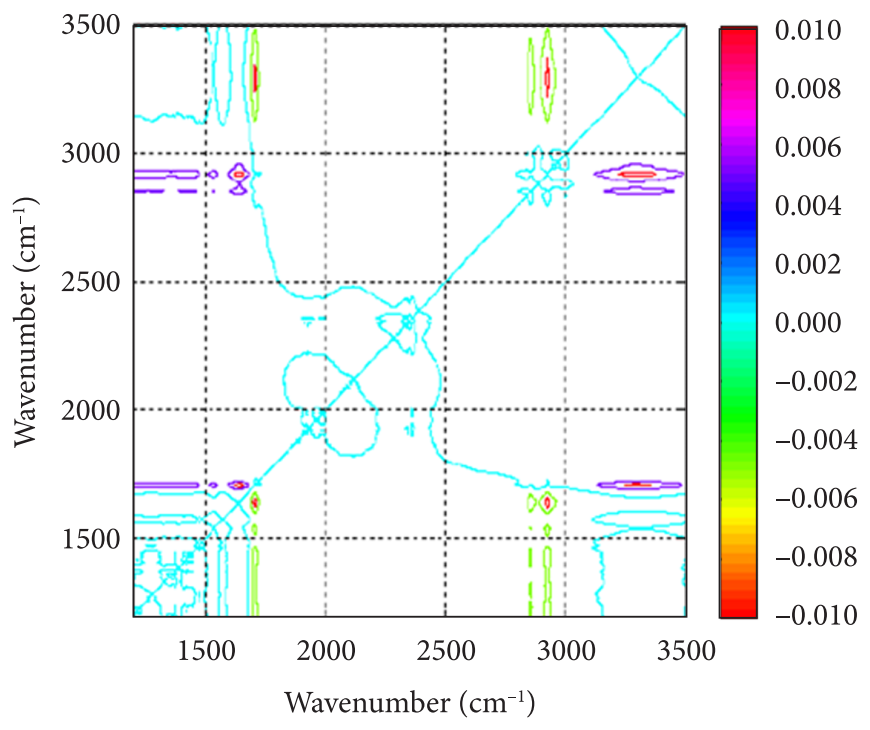

Figure 5. (a) Synchronous and (b) Asynchronous two-dimensional correlation spectrum of zein showing functional groups affected by the addition of 1,2 , and $4 \%$ Cloisite $^{\oplus} 30 \mathrm{~B}$.

1999). Between 1700 and $1600 \mathrm{~cm}^{-1}$, the peaks refer to the presence of amide I.

A second cross peak showing a wide region in $3276 \times 2932 \mathrm{~cm}^{-1}$ is due to the contribution of amide A band. However, due to the presence of another cross-peak in $2923 \times 2853 \mathrm{~cm}^{-1}$, which is probably related the stretching of the $\mathrm{CH}$ group, there is difficulty in determining which vibrational components are correlated. At $1708 \times 1652 \mathrm{~cm}^{-1}$, there is a peak identifying the correlation between the vibrational modes assigned to the oleic acid and protein secondary structure ( $\alpha$-helix).
Figure 5 shows the asynchronous obtained from the inclusion of clay Cloisite ${ }^{\circ} 30 \mathrm{~B}$ in zein film indicating two regions of negative cross peaks at $2927 \times 1648 \mathrm{~cm}^{-1}$ and in $1708 \times 1648 \mathrm{~cm}^{-1}$. In these two regions of peaks corresponding to the vibrational mode, $\beta$-sheet is $1648 \mathrm{~cm}^{-1}$, and the region of $2927 \mathrm{~cm}^{-1}$ vibrational mode corresponds to $\mathrm{CH}$ stretching. The second region of cross-peak $\left(1708 \times 1648 \mathrm{~cm}^{-1}\right)$ is derived from oleic acid and $\beta$-sheet.

According to Madejová (2003), the wave number on the montmorillonite is $3620 \mathrm{~cm}^{-1}$. However, in this study, wave number corresponding to that was not observed for both clays. This suggests that the clay did not interact with zein 
structure. Furthermore, glycerol could not be identified because its vibrational modes are overlapped by bands from zein and oleic acid.

\subsection{Functional properties}

Table 2 shows values of functional properties: opacity, water solubility, and water vapor permeability for the control film (prepared only with zein and plasticizers) and the films with 1 , 2, and $4 \%$ of Cloisite ${ }^{\circledast} 15 \mathrm{~A}$ and Cloisite ${ }^{\circledast}$ 30B.

\section{Opacity}

All zein films had higher opacity compared to polyethylene film. This is consistent according to Sessa et al. (2003) because zein has a yellow color due to presence of natural carotenoid pigments of corn, i.e., beta-carotene, lutein, and zeaxanthin. Although the control film had lower thickness than the other films with clays ( 0.19 vs. $0.22 \mathrm{~mm}$ ), there were no statistical differences of opacity among them. Thus, the differences in thickness between the samples and the amount of clay added were not relevant to influence opacity.

Opacity or translucency depends not only on the pigment staining in the matrix, but also on the presence of fatty acids. Bertan et al. (2005) found that since the addition of fatty acids increased in films produced with gelatin, opacity also increased. However, in the present study, the amount of fatty acid added (oleic acid) was constant for all sample films, so the influence of these constituents in the films could not be verified.

The presence of dispersed particles in the film with $4 \%$ of Cloisite $15 \mathrm{~A}$, reported early, suggests that the casting technique was inadequate to ensure efficient dispersion of the nanoparticles. Although the sample with $2 \%$ of Cloisite ${ }^{\circ} 15 \mathrm{~A}$ was apparently homogeneous and clay particles were not observed, this was not statistically different from the control samples and those with $4 \%$ of Cloisite ${ }^{\oplus} 15 \mathrm{~A}$.

As can be seen in the SEM images (Figure 1), most of the clay did not disperse in the polymer matrix, independently of the concentration and degree of hydrophobicity of the clay added. Again, this is an indication that the technique used for producing the films was inadequate for good mixing and interaction of the components. This may also influence the passage of light at the points in which there was less agglomeration of clay particles inside the film.
There is not enough published data correlating the addition of clay with increase or decrease in opacity of biofilms. Recently, Luecha, Sozer and Kokini (2010) prepared zein film with glycerol, polyethylene glycol (PEG), and nanometric ${ }^{\circ}$ $1.34 \mathrm{TCN}$ (modified clay) and observed absence of changes in the translucency of the films prepared with and without clay under these concentrations. However, the methodology used by these authors was qualitative through images, which is subject to misinterpretation.

\section{Water solubility}

The solubility means were not statistically different among the control samples and those added with $1 \%$ of Cloisite ${ }^{\circ}$ $15 \mathrm{~A}$ and 1,2 , and $4 \%$ of Cloisite ${ }^{\circ} 30 \mathrm{~B}$. The addition of all concentrations of Cloisite $e^{\bullet} 30 \mathrm{~B}$ was not sufficient to reduce the solubility of the sample. This similar solubility indicates once again that there was not intercalation of clay in the matrix reinforcing the idea of formation a microcomposite or tactoids.

As previously mentioned, the sample with $4 \%$ of Cloisite ${ }^{\circ}$ $15 \mathrm{~A}$ was not uniform in terms of particles dispersion. This resulted in a better permeation of water making solubility increase. Thus, the lack of incorporation of the components in the matrix contributed to the higher solubility of the sample.

Batista, Tanada-Palmu and Grosso (2005) observed that the addition of fatty acids on pectin films tended to decrease its solubility. However, the no incorporation of fatty acids in the filmogenic matrix contributed to the exposure of the hydrocolloid matrix, which promoted an increase in film solubility.

Therefore, it can be said that the non-clay dispersion in polymer matrix structure resulted in a separate phase (tactoids), which did not contribute to reduce the solubility of the film. There is no available information in the literature relating the addition of clay and increase or decrease in biofilm solubility.

\section{Water Vapor Permeability (WVP)}

Although there are statistical differences with respect to water vapor permeability (WVP) among some film samples, those were not lower than that obtained for the control. This confirms the microstructure formation of microcomposite or tactoids. If nanocomposite-type structure was formed, there would be a "tortuous path" hindering the diffusion of water and

Table 2. Opacity, Water solubility, and Water vapor permeability of zein biofilms.

\begin{tabular}{|c|c|c|c|}
\hline Samples & Opacity & Water solubility & WVP \\
\hline Polyethylene & $2.12 \pm 0.09^{\mathrm{e}}$ & - & - \\
\hline Control (Zein) & $5.81 \pm 0.20^{\mathrm{bc}}$ & $6.81 \pm 0.79^{\mathrm{ac}}$ & $0.47 \pm 0.02^{\mathrm{a}}$ \\
\hline Zein + Cloisite $^{\bullet} 15 \mathrm{~A}(1 \%)$ & $5.69 \pm 0.21^{c}$ & $5.02 \pm 0.06^{\mathrm{ab}}$ & $0.58 \pm 0.03^{\mathrm{ac}}$ \\
\hline Zein + Cloisite $^{\bullet} 15 \mathrm{~A}(4 \%)$ & $6.08 \pm 0.16^{\mathrm{a}}$ & $7.92 \pm 0.57^{c}$ & $0.55 \pm 0.01^{\mathrm{ad}}$ \\
\hline Zein + Cloisite $^{\bullet} 30 \mathrm{~B}(1 \%)$ & $5.18 \pm 0.07^{\mathrm{d}}$ & $5.76 \pm 0.90^{\mathrm{ab}}$ & $0.84 \pm 0.07^{b}$ \\
\hline
\end{tabular}

a,b,c,d and $\mathrm{e}$ - Means followed by the same letter in same column do not differ by Tukey's test $(\mathrm{p}<0.05)$. 
water vapor through the film resulting in an excellent barrier to these elements (PARK et al., 2003).

During WVP experiment, a deposition of water on the film was observed. This deposition, due to water condensation, was higher for the film samples added with Cloisite ${ }^{\otimes}$ 30B than for the control and those with Cloisite $15 \mathrm{~A}$. This observation might be due to the greater affinity to water of this type of clay, which is due to the hydrophilic hydrogen-bonds that facilitate the interaction with water. The deposition of water on the surface of the film can also be related to the characteristic permeation observed by McHugh and Krochta (1994). These authors claim that permeability is a process of condensation and diffusion, in which vapor is dissolved in one part of the film and then spreaded to the other side. In this case, there is water vapor permeation through the film and not the passage through the pores. Luecha, Sozer and Kokini (2010) prepared films of zein added with PEG (polyethylene glycol) and GLY (glycerol) by the casting method in combination with ultrasound and observed a partial exfoliation of the components. Consequently, there was a decrease in WVP compared to the control ( $0 \%$ clay) when $3 \%$ of modified clay was added. These authors claim that the type of structure formed (intercalated, exfoliated, or tactoids) contribute not only to the reduction of water vapor diffusion, but also greatly to the orientation of the clay matrix, which must rearrange itself in the perpendicular direction to the path diffusion of water vapor. Any deviation from these arrangements could result in lower property barrier. It is noteworthy that the WVP obtained for the control produced in the present study was lower than that found by the authors of a recently published study (DE ALMEIDA et al., 2010). This difference in permeability is related to the use of different plasticizers, which demonstrates that the choice of plasticizer exerts great influence on functional properties of biofilms.

Therefore, it appears that several factors may contribute to the reduction of WVP. However, to get increased barrier property to water vapor, it is necessary to choose a processing technique that can foster a good intercalation of clay in polymer matrix.

\section{Conclusions}

Although the results show agreement with other studies regarding to films property values, from the microstructure and functional property analysis, it can conclude that the films added with clays form tactoids. Therefore, these films had no better functional properties than the control sample. Thus, to increase the interaction between clays and zein matrix in order to improve films properties, other techniques of incorporation should be tested, such as ultrasonic frequency, during filmogenic solution preparation.

\section{Acknowledgements}

The authors are grateful for the financial support provide by FAPESP (The State of São Paulo Research Foundation), grant numbers 2006/01775-2 and 2008/02163-6, to the Center for Microscopy and Microanalysis of IBILCE/UNESP/SJ Rio Preto/SP, to Prof. Dr. Lilian Madi-Ravazzi for the capture of SEM imaging (FAPESP, Proc. 95/06165-1), and to the biologist Luis Roberto Faleiros for helping with sample preparation.

\section{References}

AMERICAN SOCIETY FOR TESTING AND MATERIALS - ASTM. D882-91:Standard test methods for tensile strength of plastic sheets. Philadelphia: ASTM, 2002. v. 08.01. Annual Book of American Society for Test and Material Standards.

ARORA, A.; PADUA, G. W. Review: Nanocomposites in food packaging. Journal of Food Science, v. 75, n. 1, p. 43-49, 2010. PMid:20492194. http://dx.doi.org/10.1111/j.1750-3841.2009.01456.x

BATISTA, J. A.; TANADA-PALMU, P. S.; GROSSO, C. R. F. Efeito da adição de ácidos graxos em filmes à base de pectina. Ciência $\mathbf{e}$ Tecnologia de Alimentos, v. 25, n. 4, p. 781-788, 2005. http://dx.doi. org/10.1590/S0101-20612005000400025

BERTAN, L. C. et al. Effect of fatty acids and "Brazilian elemi" on composite films base don gelatin. Food Hydrocolloids, v. 19, n. 1, p. 73-82, 2005. http://dx.doi.org/10.1016/j.foodhyd.2004.04.017

CORRADINI, E. Desenvolvimento de blendas de zeína e amido de milho. 2004. 132 f. Tese (Doutorado em Ciência e Engenharia de Materiais)-Universidade de São Paulo, São Carlos, 2004.

DE ALMEIDA, C. B. et al. Morphological and structural characteristics of zein biofilms with added xanthan gum. Food Technology Biotechnology, v. 48, n. 1, p. 19-27, 2010.

GONTARD, N.; GUILBERT, S.; CUQ, J. L. Water and glycerol as plasticizers affect mechanical and water vapour barrier properties of an edible wheat gluten film. Journal of Food Science, v. 58, n. 1, p. 206-211, 1993. http://dx.doi.org/10.1111/j.1365-2621.1993. tb03246.x

GOUNGA, M. E.; XU, S. Y.; WANG, Z. Whey protein isolate-based edible films as affected by protein concentration, glycerol ratio and pullulan addition in film formation. Journal of Food Engineering, v. 83, n. 4, p. 521-530, 2007. http://dx.doi. org/10.1016/j.jfoodeng.2007.04.008

KLEEN, D.; PADUA, G. W.; ENGESETH, N. Stabilization of lipids in a biodegradable zein-oleate film by incorporation of antioxidants. Cereal Chemistry, v. 79, n. 5, p. 687-694, 2002. http://dx.doi. org/10.1094/CCHEM.2002.79.5.687

LAWTON, J. W. Zein: A history of processing and use. Cereal Chemistry, v. 79, n. 1, p. 1-5, 2002. http://dx.doi.org/10.1094/ CCHEM.2002.79.1.1

LEE, D. H.; CONDRATE, R. A. FTIR spectral characterization of thin film coatings of oleic acid on glasses: I. Coatings on glasses from ethyl alcohol. Journal of Materials Science, v. 34, n. 1, p. 139-146, 1999. http://dx.doi.org/10.1023/A:1004494331895

LUECHA, J.; SOZER, N.; KOKINI, J. F. Synthesis and properties of corn zein/montmorillonite nanocomposite films. Journal Material Science, v. 45, n. 3, p. 3529-3537, 2010. http://dx.doi.org/10.1007/ s10853-010-4395-6

MADEJOVÁ, J. Review: FTIR techniques in clay mineral studies. Vibrational Spectroscopy, v. 31, n. 1, p. 1-10, 2003. http://dx.doi. org/10.1016/S0924-2031(02)00065-6

McADAM, C. P.; HUDSON, N. E.; PETHRICK, R. A. Synthesis and characterization of nylon 6/ clay nanocomposites prepared by ultrasonication and in situ polymerization. Journal of Applied Polymer Science, v. 108, n. 4, p. 2242-2251, 2008. http://dx.doi. org/10.1002/app.25599

McHUGH, I. H.; KROCHTA, J. M. Permeability properties of edible films. In: KROCHTA, J. M.; BALDWIN, E. A.; 
NISPEROS-CARRIEDO, M. O. Edible coatings and films to improve food quality. Pennsylvania: CRC Press, 1994. chap. 6, p. 139-183.

MONTERREY-QUinTero, E. S.; SOBRAL, P. J. A. Preparo e caracterização de proteínas miofibrilares de tilápia-do-nilo para elaboração de biofilmes. Pesquisa Agropecuária Brasileira, v.35, n. 1, p.179-189, 2000. http://dx.doi.org/10.1590/S0100204X2000000100020

NODA, I. Two-dimensional correlation analysis of unevenly spaced spectral data. Applied Spectroscopy, v. 47, n. 8, p. 1049-1051, 2003. PMid:14661850. http://dx.doi.org/10.1366/000370203322259039

PADUA, G. W.; WANG, Q. Formation and properties of corn zein films and coatings. In: GENNADIOS, A. Protein-based films and coatings. Boca Raton: CRC Press, 2002. chap. 2, p. 43-67.

PARK, H. W. et al. Environmentally friendly polymer hybrids: Part I. Mechanical, thermal, and barrier properties of thermoplastic starch/clay nanocomposites. Journal of Materials Science, v. 38, n. 5, p. 909-915, 2003. http://dx.doi.org/10.1023/A:1022308705231

PAVLIDOU, S.; PAPASPYRIDES, C.D. A review on polymer-layerd silicate nanocomposites. Progress in Polymer Science, v. 33, n. 12, p. 1119-1198, 2008. http://dx.doi.org/10.1016/j. progpolymsci.2008.07.008
SANCHEZ-GARCIA, M. D.; HILliOU, L.; LAGARON, J. M. Nanobiocomposites of carrageenan, zein, and mica of interest in food packaging and coating applications. Journal of Agricultural and Food Chemistry, v. 58, n. 11, p. 6884-6894, 2010. PMid:20455568. http://dx.doi.org/10.1021/jf1007659

SESSA, D. J. et al. Improved methods for decolorizing corn zein. Industrial Crops and Products, v. 18, n. 1, p. 55-65, 2003. http:// dx.doi.org/10.1016/S0926-6690(03)00033-5

SORRENTINO, A.; GORRASI, G.; VITTORIA, V. Potential perspectives of bio-nanocomposites for food packaging applications. Trends in Food Science and Technology, v. 18, n. 2, p. 84-95, 2007. PMid:21299575. http://dx.doi.org/10.1016/j.tifs.2006.09.004

SOZER, N.; KOKINI, J. L. Review: Nanotechnology and its applications in the food sector. Trends in Biotechnology, v. 27, n. 2, p. 82-89, 2009. PMid:19135747. http://dx.doi.org/10.1016/j. tibtech.2008.10.010

WANG, Y. et al. Effects of processing on the structure of zein/oleic acid films investigated by X-ray diffraction. Macromolecular Bioscience, v. 5, n. 12, p. 1200-1208, 2005. PMid:16315186. http:// dx.doi.org/10.1002/mabi.200500140

YU, L.; DEAN, K.; LI, L. Polymer blends and composites from renewable resources. Progress in Polymer Science, v. 31, n. 6, p. 576-602, 2006. http://dx.doi.org/10.1016/j.progpolymsci.2006.03.002 